\title{
DISCUSSION OF JURASSIC LITHOSTRATIGRAPY IN THE DANISH, DUTCH, AND NORWEGIAN CENTRAL GRABEN AREAS
}

\author{
O. Michelsen ${ }^{1} \&$ Th. E. Wong ${ }^{2}$ \\ ${ }^{1}$ Geologisk Institut, Aarhus Universitet, DK-8000 Aarhus C, Denmark. \\ ${ }^{2}$ Geological Survey of The Netherlands, P.O. Box 157, 2000AD Haarlem, The Netherlands.
}

\section{Abstract}

Based on recently published data dealing with the Jurassic lithostratigraphy from the Danish, Dutch, and Norwegian sectors of the Central Graben areas, it seems possible to establish a more consistent and dynamic stratigraphic scheme for these regions. A preliminary proposal of a south-north lithostratigraphic section, from the Dutch to the southern Norwegian sector is discussed. It is suggested to initiate an international cooperation in order to study the common geological features in detail.

\section{Introduction}

Since the publication of Rhys (1974) on the "lithostratigraphic nomenclature" in the southern North Sea various papers, dealing with the Jurassic lithostratigraphy in the Central North Sea, have appeared. At the same time, the amount of available well data has increased considerably, leading to even more reliable lithostratigraphic subdivisions within each of the national sectors of the North Sea. Correlation between these sectors still needs to be discussed between the geoscientists from the countries involved. This paper, which is a joint contribution of the geological surveys of Denmark and The Netherlands, could be a first step for future international coorperation.

\section{Lithostratigraphy}

\section{General}

In this chapter we will discuss several Jurassic lithological units from the Danish, Dutch, and southern Norwegian sectors which are thought to surpass national boundaries (see fig.1, for the area dealt with). The discussion is gennerally referring to the following papers:

Jensen et al. (1986) and Michelsen et al. (1987) for the Danish sector. NAM \& RGD (1980), Herngreen \& de Boer (1984), and Herngreen \& Wong (1989) for the Dutch sector. Vollset \& Doré (1984) and Bergan et al. (1989) for the Norwegian sector.

\section{Danish sector}

The Jurassic-Lower Cretaceous lithological scheme of the Danish Central Trough was described by Jensen et al. (1986) and it will be shortly reviewed below in stratigraphic order, from old to young:

\section{Fjerritslev Formation}

This Lower Jurassic formation consists of dark grey claystones interbedded with thin marlstones. It has a very characteristic logpattern, which allows long distance correlation between the Danish Subbasin (where the formation was established), the Danish 


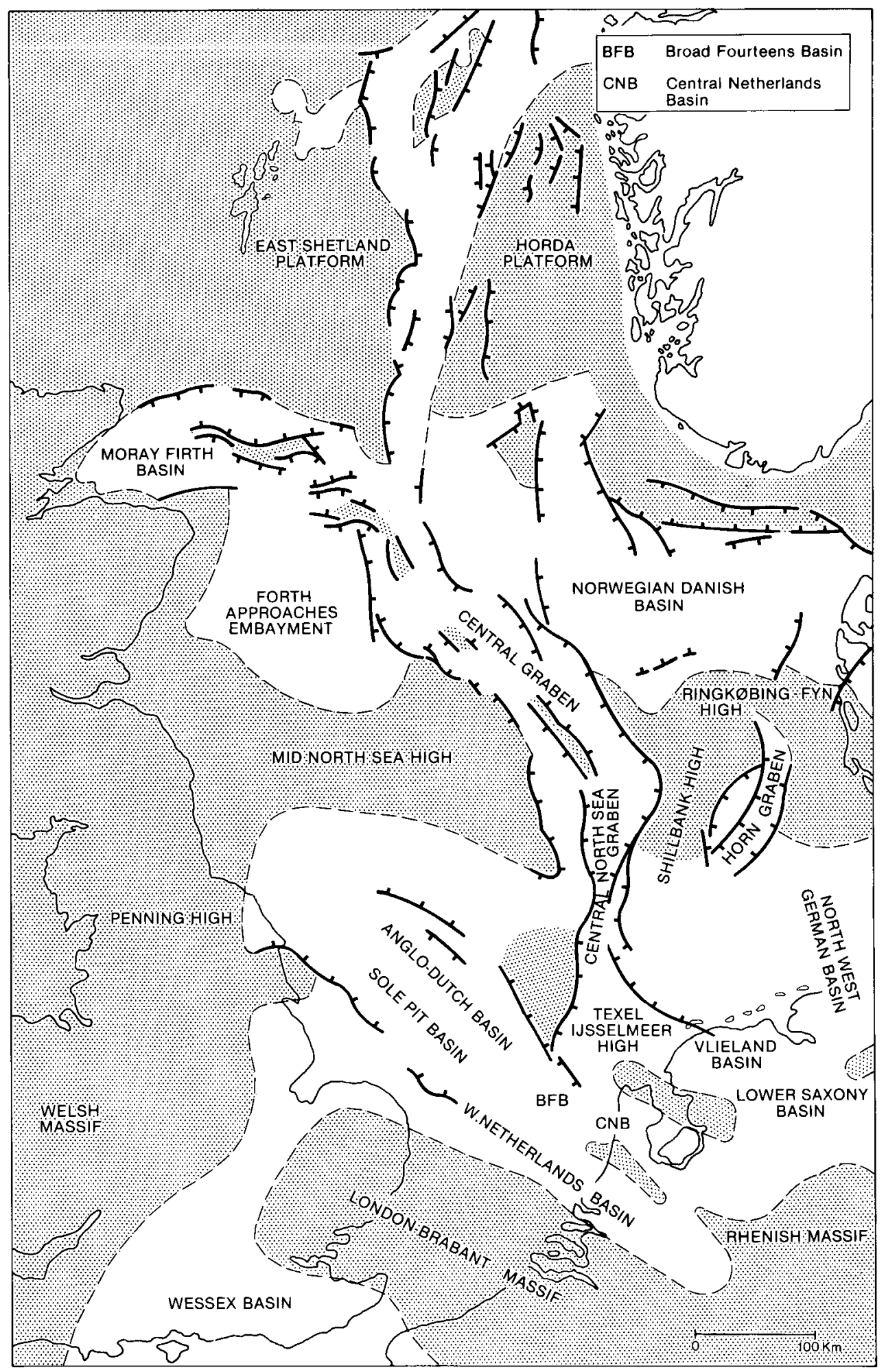

Fig. 1: Structural framework of the North Sea, including the study area (from Herngreen \& Wong 1989). 
Central Trough, and the southern Norwegian sector.

\section{Lower Graben Sand Formation}

In Denmark this formation has a wide-ranging Middle Jurassic age (Bajocian to Callovian), whereas in The Netherlands the age is Middle to Late Callovian only. The formation is characterized by rather thick sandstone units interbedded with claystones, siltstones and heteroliths. Thin coalbeds are intercalated towards the east in the Central Trough. The formation was established in the Dutch sector (NAM \& RGD 1980) and extends into the southern Danish sector.

\section{Middle Graben Shale Formation}

In Denmark the age of this formation is Callovian, but in The Netherlands only Late Jurassic (Oxfordian) ages have been recorded. This formation comprises claystones with siltstones and sandstones. A few coalbeds may be present in the lower part of the formation. In the Dutch sector, where this formation was established (NAM \& RGD 1980), the boundary with the underlying Lower Graben Sand Formation has been placed by Herngreen \& Wong (1989) at the base of the lowermost coalbed. The formation extends from the Dutch sector into the southern Danish sector.

\section{Bryne Formation}

This Middle Jurassic formation consists of sandstones with numerous interbedded siltstones and claystones. Scattered coalbeds occur and all lithologies contain carbonaceous material of varying sizes. The formation was established in the Norwegian sector (Vollset \& Doré 1984), and is known from the Søgne Basin and the Tail End Graben in the Danish sector.

\section{Basal sand}

This Oxfordian unit was recognized in the Norwegian sector (Bergan et al. 1989) as an approximately $100 \mathrm{~m}$ thick sequence of shallow marine sandstones. The section is probably identical to the one seen in the lowermost part of the Karl-1 and Gert-1 wells in the northern Danish sector. Until further data are available, the sequence is regarded as a coast near deposit, resulting from the transgression following deposition of the Bryne Formation. The basal sand is overlain by the marine claystones of the Lola Formation.

\section{Heno Formation}

This Late Oxfordian to Kimmeridgian formation consists of sandstones and siltstones interbedded with claystones and heteroliths. It is locally situated between the Lola and Farsund Formations, representing a period of regression. The formation has been established in the Danish sector at the Heno Plateau (Jensen et al. 1986), but it also seems to be present in the southern Norwegian sector. There, it is preliminarily named the Heno Formation Equivalent (Bergan et al. 1989).

\section{Lola Formation}

This Oxfordian to Kimmeridgian formation is characterized by slightly calcareous claystones with organic material of terrestrial origin. The formation is present in the entire Danish sector and, according to Bergan et al. (1989), it is also recognized in the southern Norwegian sector. There it is regarded as a member of the Haugesund Formation.

\section{Farsund Formation}

This Kimmeridgian to Ryazanian formation mainly consists of claystones with numerous thin dolomitic or limestone beds which generate the well-known log-motifs. The organic material is predominantly of marine origin. The formation was established in the Norwegian sector (Vollset \& Doré 1984) and it is also present in the entire Danish Central Trough. 


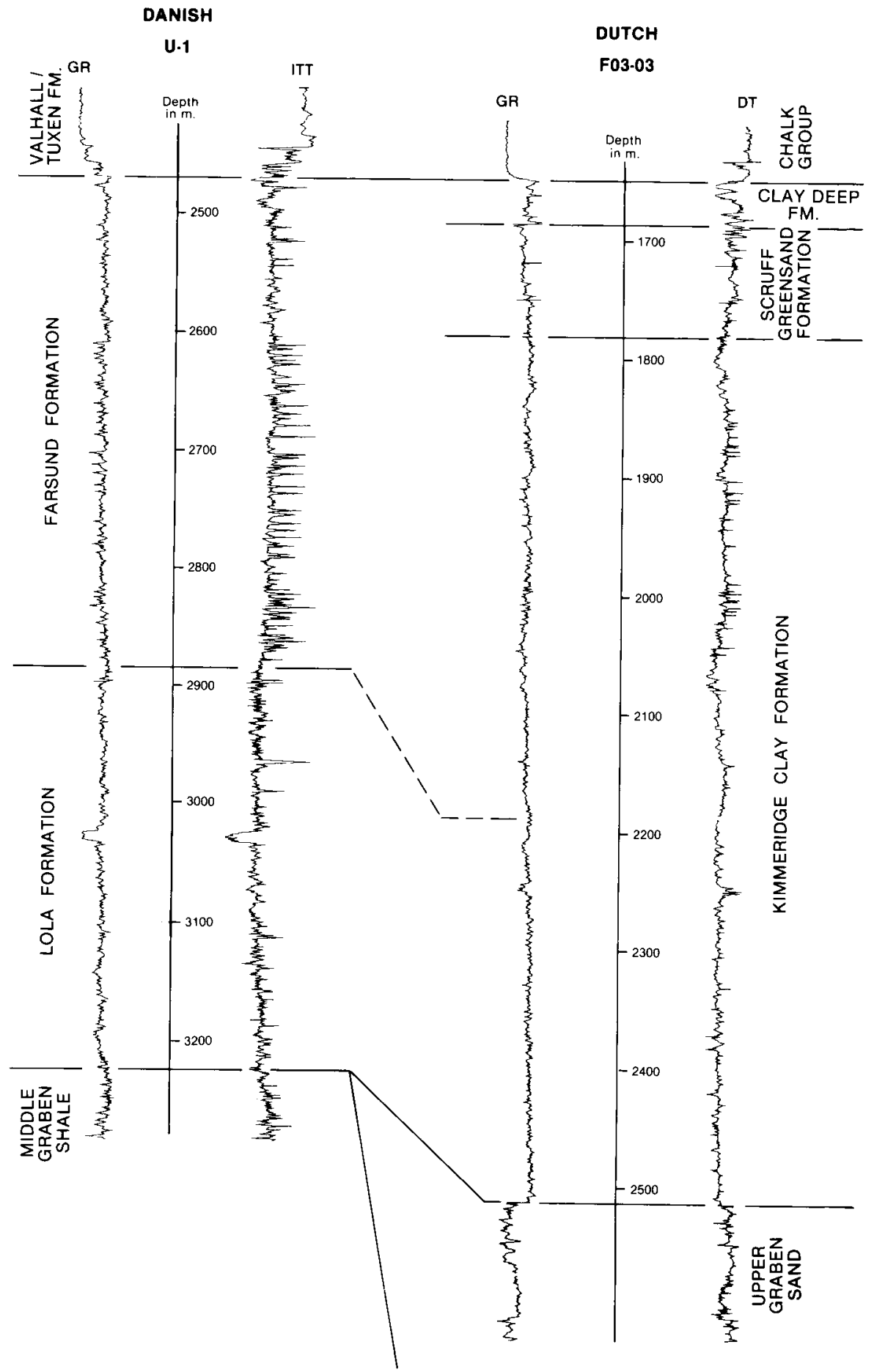

Fig. 2: Preliminary lithostratigraphic correlation of the Lola and Farsund Formations in the Danish U-1 well and the Kimmeridge Clay Formation in the Dutch F3-3 well, indicating a possible extension to the south of the two first-mentioned formations. 


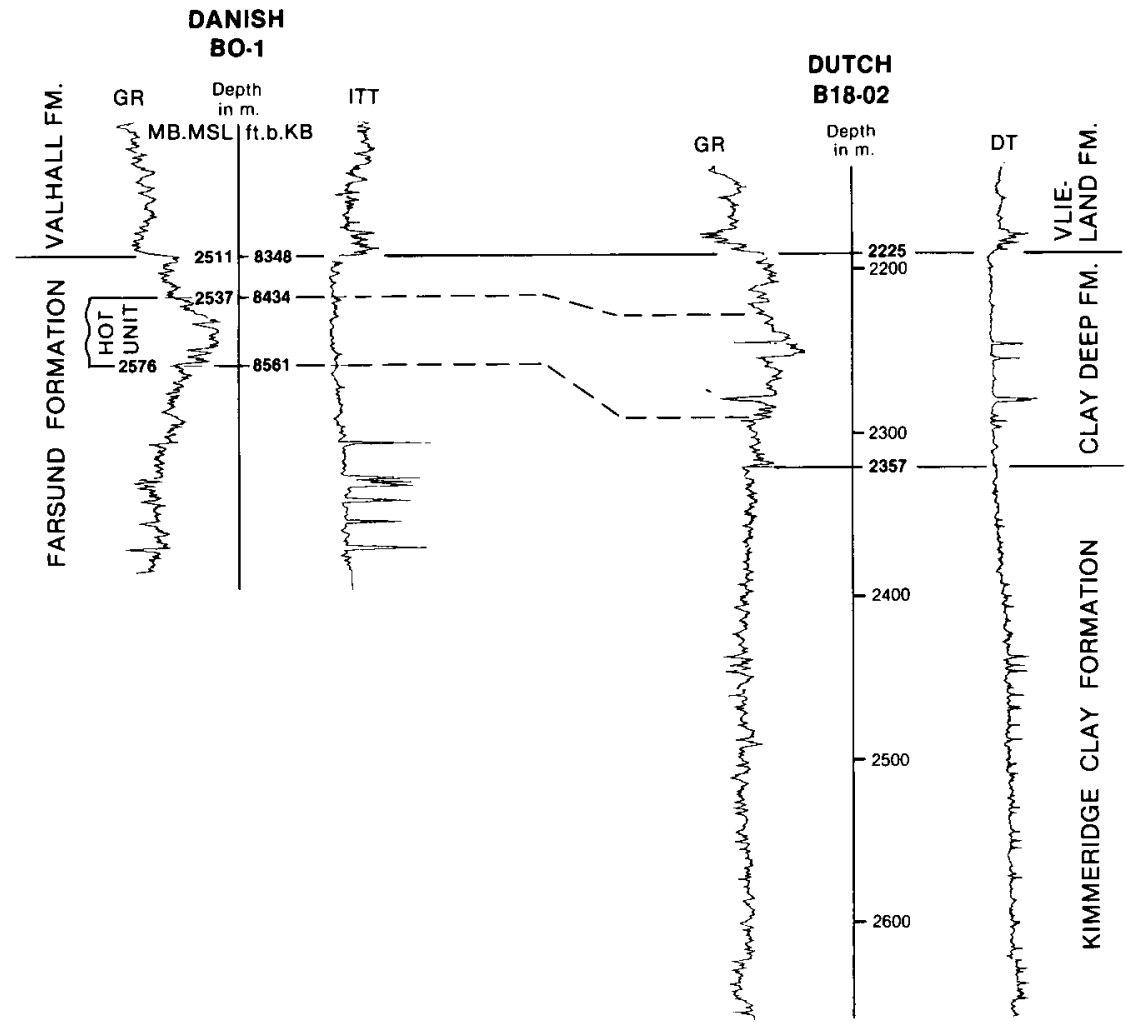

Fig. 3: Preliminary correlation of the hot unit in the Danish Bo-1 well and the carbonaceous part of the Clay Deep Formation in the Dutch B18-2 well. The log-readings suggest that the occurrence of local, highly carbonaceous sedimentary facies at the Jurassic-Cretaceous boundary is a wide-spread feature.

\section{Hot unit}

The uppermost, Late Volgian (Late Portlandian) to Early Ryazanian, part of the Farsund Formation may be highly carbonaceous, which is recognized by high gamma ray readings. In the Danish sector, this sector is informally named the hot unit (Jensen et al. 1986). It is equivalent with the Norwegian Mandal Formation, but may not be one single coherent sedimentary body. We merely regard the hot unit as a sedimentary facies variation of the Farsund Formation.

\section{Poul Formation}

To complete the review of the Danish Jurassic formations, the Volgian (Late Kimmeridgian to Portlandian) Poul Formation must be mentioned. It consists of partly ar- gillaceous siltstones and fine-grained sandstones, which probably were deposited as gravity flows. It occurs along the eastern margin of the Danish Central Trough, interbedded in the Farsund Formation. This formation will not be further discussed in this paper, since it has a limited lateral extension.

\section{Dutch sector}

Recently, Herngreen and Wong (1989) revised the "Late Jurassic" stratigraphy of the Dutch Central North Sea Graben. The sediments discussed, range in age from Callovian to Ryazanian. They are grouped in two, partly time-equivalent, lithological units (see fig. 4): a mainly non-marine Central Graben Group (with the Lower Graben Sand, Middle Graben Shale, Upper Graben 


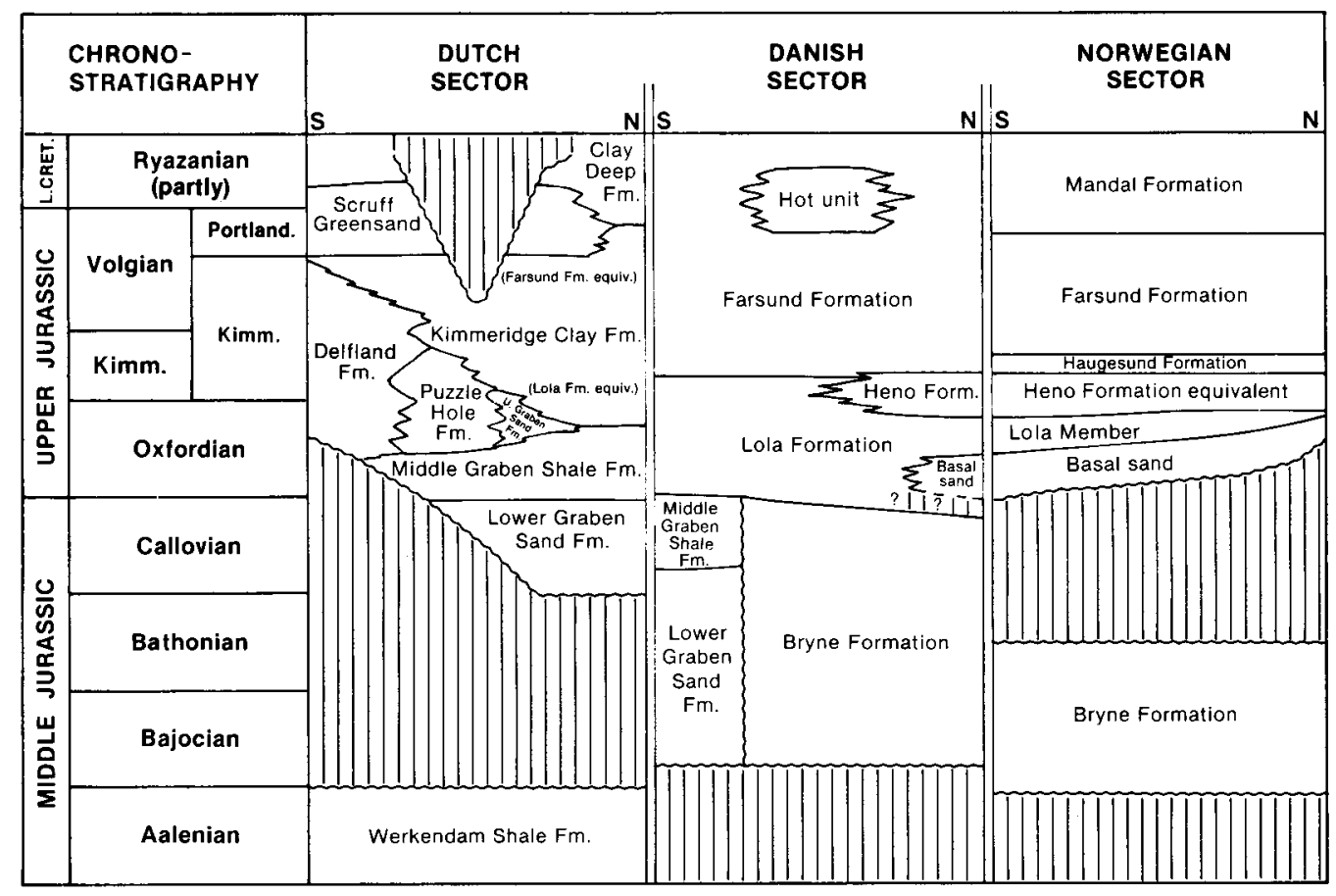

Fig. 4: Combined south-north lithostratigraphic section through the Dutch, Danish, and Norwegian sectors (modified from Bergan et al. 1989, Herngreen \& Wong 1989, Jensen et al. 1986, and Vollset \& Doré 1984). The section is situated approximately in the central to eastern parts of the Danish and Norwegian sectors. It suggests a possible extension of the rock units across the national borders as discussed in text. Since the German sector is not included, a close tie between the Dutch and Danish sectors can not be expected in this figure.

Sand, Puzzle Hole, and Delfland Formations) and the distinct marine Scruff Group (with the Kimmeridge Clay, Scruff Greensand, and Clay Deep Formations).

As already mentioned, the Lower Graben Sand and Middle Graben Shale Formations can easily be extended into the Danish sector. Therefore, the attention will be focussed here on the overlying Late Jurassic sediments.

\section{Kimmeridge Clay Formation}

In the Dutch sector this formation rests conformably on sediments of the Central Graben Group. Generally, the formation is conformably overlain by either the Scruff Greensand or the Clay Deep Formation. In the northern part of the Dutch Central North Sea Graben, the age of the Kimme- ridge Clay ranges from mid Oxfordian to Middle Volgian. In this area, Herngreen \& Wong (1989) noted that a twofold division can be made of the formation. The upper part is characterized by the presence of numerous dolomitic beds, whereas the lower part is predominantly clayey. The same authors reported the presence of a slight intraformational unconformity which seems to coincide with the boundary between these lithologies. They also emphasized the similarity with the Danish Central Trough in which the upper and lower units are named Farsund and Lola Formations, respectively. Pending further investigation, it was decided not to introduce new formation names but to maintain the well-established Dutch nomenclature.

If we compare the Danish and the Dutch reference wells, respectively $U-1$ and F3-3, 
there appears to be a good lithostratigraphic correlation (fig. 2). True lithostratigraphic conclusions can obviously not be drawn from this correlation, but it supports the assumption that further investigations of relevant Danish and Dutch wells possibly may lead to the extension of the Lola and Farsund Formations to the south. Local developments within the Kimmeridge Clay in the Dutch sector (e.g. the disappearance of dolomitic streaks and the increased silty character towards the south) also need to be studied in detail.

\section{Clay Deep Formation}

This is a new name proposed by Herngreen \& Wong (1989) for a rather bituminous claystone that conformably overlies the Kimmeridge Clay Formation in the northern part of the Dutch Central North Sea Graben. It was also stated that the formation differs from the Kimmeridge Clay by the absence of well-developed dolomite stringers. Furthermore, the bituminous character of the formation decreases toward the south, where the formation is reported to conformably overly the Scruff Greensand Formation. In this southern realm the Clay Deep Formation is rather difficult to recognize because the gamma ray readings are rather low, corresponding to a normal clay level. In general however, these readings are slightly higher than those of the overlying claystones of the Vlieland Formation. As far as the dolomite stringers are concerned, it is known from Danish well data that density and number of these stringers vary greatly. This feature may, therefore, not alone be diagnostic in the lithostratigraphic discussion.

Herngreen \& Wong (1989) already pointed to a possible relationship with similar hot units from Norway and Denmark, stating that the Clay Deep Formation represents one of the southernmost occurrences of the Kimmeridge Clay "hot shale" facies of Barnard \& Cooper (1981) in the North Sea area. If we compare the only Dutch well showing extremely high gamma ray readings of the Clay Deep Formation, the B18-2 well, with the Danish type section of the hot unit, the Bo-1 well, a close resemblance is apparent (fig. 3). In both sections, the hot unit interval comprises dolomitic stringers.

It is evident that, also in this case, we need to study more data from Danish and Dutch wells before we can make any revision. At present it seems likely that a hot unit is present in the Dutch sector but it is still open for discussion if the remaining (non-bituminous) part of the Clay Deep Formation should be referred to the Kimmeridge Clay (or the Farsund Formation).

\section{Norwegian sector}

In fig. 4 the lithostratigraphic scheme of the Jurassic in the southern Norwegian sector is presented.

\section{Basal sand}

This is the oldest Late Jurassic (Oxfordian) formation recorded in the southern Norwegian sector. It has been interpreted as shallow marine sands deposited during the transgression, which came from the north. It is covered by the deeper marine deposits of the Lola Formation (ranked as a member of the Haugesund Formation).

\section{Heno Formation Equivalent}

In all well sections shown by Bergan et al. (1987), the Lola Formation is separated from the more sandy Haugesund Formation by the Heno Formation Equivalent, which they correlate to the Heno Formation in the Danish Q-1 well. This unit may therefore be regarded as the northern extension of the Heno Formation.

\section{Haugesund Formation}

This formation comprises sandy claystones. It has not yet been recognized within the Danish sector. Since it overlies the Heno 
Formation it may be approximately timeequivalent to the lower Farsund and upper Lola Formations.

\section{Farsund Formation}

Since this formation, including the hot units, has a uniform appearance in the Norwegian and Danish sectors no further discussion is needed.

\section{Mandal Formation}

The highly bituminous claystones seem to be comparable to the hot units in the Danish and Dutch sectors, but further research is required to unravel their relationship.

\section{Conclusion}

Having identified several common features within the Upper Jurassic stratigraphy of Denmark, the Netherlands, and Norway it seems appropriate to suggest a cooperation across the national boundaries. We think that it should be possible to establish a consistent use of lithostratigraphic names, extending the formations outside the national sectors. In combination with further biostratigraphy and structural studies, a revised lithostratigraphy will contribute to a better and more dynamic description of the basin development.

In fig. 4 we present a preliminary proposal of a south-north lithostratigraphic section (from the Dutch sector to the southern Norwegian sector). At present, we do not have data from the intermediate German sector which makes a close tie between the Dutch and Danish sectors difficult. Despite this drawback, our section seems to represent a consistent picture which we can summarize as follows:

1. On top of the fluvial to shallow marine Middle Jurassic Bryne Formation and Central Graben Group, marine clays (Lola Formation) were deposited in the central part of the area whereas, at structural highs, transgressive sands (Basal sands) accumulated. During the following regression sand of the Heno Formation was deposited in the Danish and Norwegian sectors. Both units are timeequivalent with the Delfland and Puzzle Hole Formations.

2. Marine clays were uniformly deposited over large areas, resulting in the Lola and Farsund Formations.

3. Intercalations of sandy units as the Poul Formation in the Farsund Formation (and probably also in the Dutch Kimmeridge Clay Formation) are due to local sedimentary processes.

4. At the Jurassic-Cretaceous boundary, organic rich clays (hot units) were deposited, probably in local sub-environments.

\section{References}

Barnard, P. C. \& Cooper, B. S., 1981: Oils and source rocks of the North Sea area. In: Illing, L. V. \& G. D. Hobson (eds.): Petroleum Geology of the continental shelf of Northwest Europe - Inst. of Petroleum, London: 169-175.

Bergan, M., Tørudbakken, B. \& Wandås, B., 1987: Stratigraphic correlation of Upper Jurassic sandstones within the Central Graben: Sedimentological and tectonic implications. In: Collinson, J. (ed.): Correlation in hydrocarbon exploration. Graham \& Trotman, London, 243-253.

Herngreen, G. F. W. \& de Boer, K. F., 1984: Palynology of the "Upper Jurasic" Central Graben, Scruff and Delfland Groups in the Dutch part of the North Sea continental shelf. - In: Michelsen, O. \& Zeiss, A. (eds.): International Symposium on Jurassic stratigraphy. Erlangen. Copenhagen, pp. 695-714.

Herngreen, G. F. W. \& Wong, T. E., 1989: Revision of the "Late Jurassic" stratigraphy of the Dutch Central North Sea Graben. Geologie en Mijnbouw, 68, 73-105.

Jensen, T. F., Holm, L., Frandsen, N. \& Michelsen, O., 1986: Jurassic - Lower Cretaceous lithostratigraphic nomenclature for the Danish Central Trough. Danm. geol. Unders., Serie A, no. 12, 65 pp.

Michelsen, O., Frandsen, N., Holm, L., Jensen, T. F., Møller, J. J. \& Vejbæk, O. V., 1987: JurassicLower Cretaceous of the Danish Central Trough; - depositional environments, tectonism, and res- 
ervoirs. Danm. geol. Unders., Serie A, no. 16, 45 pp.

NAM \& RGD (Nederlandse Aardolie Maatschappij B. V. \& Rijks Geologische Dienst), 1980: Stratigraphic nomenclature of the Netherlands. Verh. Kon. Ned. Geol. Mijnbouwk. Gen., 32, 77 pp.

Rhys, G. H., 1974: A proposed standard lithostratigraphic nomenclature for the southern North
Sea and an outline structural nomenclature for the whole of the (U. K.) North Sea. Inst. Geol. Sci., Report 74/8, $14 \mathrm{pp}$.

Vollset, J. \& Doré, A. G. (eds.), 1984: A revised Triassic and Jurassic lithostratigraphic nomenclature for the Norwegian North Sea. NPD-Bulletin no. 3 , Stavanger, $53 \mathrm{pp}$. 